\title{
INVESTIGATIONS IN INTENSIFICATION OF GRAIN DRYING BY ACTIVE VENTILATION APPLYING OZONE
}

\author{
Adolfs Rucins $^{1}$, Dainis Viesturs ${ }^{1}$, Alberts Kristins ${ }^{2}$, Juris Bruveris ${ }^{3}$ \\ ${ }^{1}$ Latvia University of Life Sciences and Technologies, Latvia; ${ }^{2}$ Institute of Solid State Physics, \\ University of Latvia, Latvia; ${ }^{3}$ SIA "Ozone Tech", Latvia \\ adolfs.rucins@1lu.lv
}

\begin{abstract}
The article presents an analysis of the previous research on the use of ozone for intensified active ventilation of grain and develops a methodology for experiments to evaluate the usefulness of ozone utilisation in ventilation in farm conditions. The essence of the experiments: two identical tanks are loaded with the same amount of grain of the same humidity and are ventilated with the same intensity of air flow by adding to the ventilation air of one tank ozone, produced by the generator. The sensor systems installed in the tanks record the drying process parameters. The sensor systems, developed and installed in the tanks, worked without fail, providing a possibility to follow the ventilation modes in the computer, both on the farm, and remotely. During the experiments a small reduction in the moisture content of the grain in the ozone tank was consistently observed in several aspects, as compared to the tank without the ozone admixture to the ventilation air, yet the advantages of the method have not been convincingly proved. Therefore, experiments should be continued in 2020 during grain harvesting by ventilation in both tanks for grain, 3.0-3.5 m high. It has been proved during the experiments that, using active ventilation, we can prepare extra quality food grain for sale, reducing the humidity by $7.0-8.0 \%$.
\end{abstract}

Keywords: grain, drying, active ventilation, ozone, sensor systems.

\section{Introduction}

Research into the use of ozone in grain processing and storage began already in the middle of the last century. They are developed in several directions - the use of ozone to control harmful microorganisms and pests during grain storage, to improve the properties of flour and other products, to improve the seed quality. The use of ozone for the grain drying intensification has also been rather extensively studied, yet more often under the laboratory conditions - for processing a small amount of grain and a relatively thin layer of grain. The work [1] investigates the effect of ozone in comparison with the drying rates under two identical laboratory conditions - in one ventilating with clean air and in the other with air having ozone added. Experiments [2] were carried out in a $0.45 \mathrm{~m}$ high column with the ventilation length for up to an hour. The authors of publication [3] also carried out experiments in the laboratory with a few tens of kilograms of grain and a layer of grain up to $1.2 \mathrm{~m}$ thick. The author of publication [4], in turn, has worked with a grain layer up to $0.5 \mathrm{~m}$ thick, the ozone concentration $2.4-8.2 \mathrm{mg} \cdot \mathrm{m}^{-3}$, the initial humidity of grain $17-28 \%$; and he believes that the ozone addition to the ventilation air allows reducing the duration of ventilation by $10-20 \%$.

Initially the author of [5] also carried out experiments with a $0.1 \mathrm{~m}$ thick grain layer, ozone concentration $9 \mathrm{mg} \cdot \mathrm{m}^{-3}$, initial grain moisture $26 \%$. The authors of [6] also worked with the original laboratory equipment, periodically ventilating a grain layer up to $1 \mathrm{~m}$ high for 8 days, reducing the grain moisture from $23-14 \%$. Up to $0.3 \mathrm{~m}$ thick layer has been ventilated also by the author [7] in experiments; she recommends an ozone concentration of $8-10 \mathrm{mg} \cdot \mathrm{m}^{-3}$, with the initial humidity changed in a wide range. Most authors [1;3-5] have worked in their experiments with air flow rates of $0.2-0.4 \mathrm{~m} \cdot \mathrm{s}^{-1}$, ozone concentrations of $2.4-10 \mathrm{mg} \cdot \mathrm{m}^{-3}[4 ; 5 ; 7]$. All the authors believe that the presence of ozone in the grain drying process shortens the drying time, some [4-7] report numerical values 15$35 \%$.

However, several researchers also consider the use of ozone to intensify drying tens of tons of grain and several meter thick layer of grain. The authors of [8] have worked with a $2.7 \mathrm{~m}$ thick grain layer and 10-20 ppm (21.0-42.0 $\left.\mathrm{mg} \cdot \mathrm{m}^{-3}\right)$ ozone concentration at farm conditions, although the authors do not mention the efficiency of the process [9], in turn, to ventilate in large-volume tanks, it uses air heated by $5^{\circ} \mathrm{C}$ with an ozone concentration of $3-5 \mathrm{mg} \cdot \mathrm{m}^{-3}$ and an air supply of $250 \mathrm{~m}^{3} \cdot \mathrm{h}^{-1}$ per ton of grain. It is considered that such conditions reduce the drying time by up to $20 \%$. Several authors $[4 ; 5 ; 7]$ briefly describe at the end of their laboratory investigations also the comparative grain drying, conducted on farms, in 30m3 tanks, using ozone. So, in a 9-11 days experiment [4] it has reduced the grain moisture by $24-14 \%$, besides, using ozone, the drying period was two days shorter. No other 
parameters of the process are specified. Similar results have [5] - the experiments were carried out in two tanks of $30 \mathrm{~m}^{3}$ volume, both using by $5-6^{\circ} \mathrm{C}$ warmed air, in one tank adding ozone concentration of $3-5 \mathrm{mg} \cdot \mathrm{m}^{-3}$ to the ventilation air, the other tank being ventilated without ozone. Such a ventilation mode is considered to reduce the drying time by about $20 \%$. On the other hand, [7] confines to the conclusion that using ozone increases the drying rate up to two times, without specifying the process parameters either.

All the authors come to a conclusion that the use of ozone in grain drying with active ventilation speeds up the process, yet the stated effect in terms of shortening the drying time is from 10 even to $100 \%$, in most cases only from 10 to $25 \%$. In most cases the concentration of the used ozone is 5$30 \mathrm{mg} \cdot \mathrm{m}^{-3}$, the initial grain moisture is $28-18 \%$. The grain drying time in the experiments was from a few hours in the laboratory to 12 days in large-volume containers.

On the whole, the ozone application modes and results in grain drying with active ventilation in large-volume tanks are insufficient and sometimes even contradictory reflected, therefore, the aim of the research is to experimentally test the possibilities of intensified grain drying using ozone under the farm conditions, by ventilating moist grains in $22 \mathrm{~m}^{3}$ tanks.

\section{Materials and methods}

The experiments on active ventilation of grain drying were carried out in two identical square cross-section tanks with a maximum capacity of 20 tons - one with ventilation of unheated outdoor air, the other with addition of ozone to the unheated outdoor air (Fig. 1a). The grain pre-treatment point, tanks for ventilation experiments and grain were provided by Mazkalnini peasant farm, Tērvete District. To prepare the tanks for experiments, the following steps were taken:

- fans were installed and connected to each tank with a $7000 \mathrm{~m}^{3} \cdot \mathrm{h}^{-1}$ capacity, $2800 \mathrm{~min}^{-1}$ working speed of the impeller and $4.0 \mathrm{~kW}$ engine capacity;

- each fan and ozone generator is ensured with separate metering of the consumed electric energy;

- the fan to which the ozone generators OPV-100.03 (OOO НПО “ЖемчужинаРуси”, RU, http://www.bakteriy.net/) are connected with a total ozone output of $200 \mathrm{~g} \cdot \mathrm{h}^{-1}$ and an approximate installed power of $2 \mathrm{~kW}$ ensures a possibility to regulate the impeller speed and thus productivity;

- a suspension is mounted in the centre of each tank for mounting the sensor system by placing the sensor boxes after every meter.

As a suspension for fixing the sensor system, there is chosen a $40 \mathrm{~mm}$ plastic pipe in which the wires connecting the sensors, arranged on five levels, are placed. Five sensor protective boxes are clamped to the pipe with a metre interval, approximately $40 \%$ of the surface area being covered with a fine metal mesh (Fig. 1c). The mesh provides access to the sensors of air, ozone and moisture in the inter-grain space, but separates them from grain. Each box contains a sensor system element with integrated humidity $\mathrm{RH}$, temperature $\mathrm{T} 0$, and ozone concentration $\mathrm{O} 3$ sensors (Fig. 1b) for a grain tank with ozone supply, and integrated RH and T0 sensors for a grain tank without ozone. The sensor system elements are correspondingly interconnected and connected above the tank to a data transmission module, consisting of a microcontroller with memory, a power supply and an E-32 data transmission module with an antenna. These elements together form a sensor system that, with the already mentioned E-32 transmission module, transmits data to a remotely mounted reception module which, in turn, is connected via a USB cable to a computer.

During the experiments, by means of stationary meters the energy consumption of the fans and the ozone generators was determined, by means of a sensor system - the air humidity $(\mathrm{RH}, \%)$ and temperature $(\mathrm{T}, 0 \mathrm{C})$ of both tanks on the five layers of the inter-grain space, ozone concentration $(\mathrm{O} 3$, ppm) in a tank with the ozone supply in five layers, as well as humidity and temperature in the ambient air. For additional control of the drying process, by the hand tool Wile 66 (FarmComp Oy, Finland) the grain moisture was periodically measured in several layers of the tank, while by the QL800-O3 (QLOZONE, China) the ozone concentration was measured at the top of the tank. A hand tool is also used to control the air flow speed at the top of the tanks. Measurement accuracy: humidity $+4.5 \% \mathrm{RH}$; temperature $+0.5{ }^{\circ} \mathrm{C} ; \mathrm{O}_{3}+5 \%$ max of the reading. 


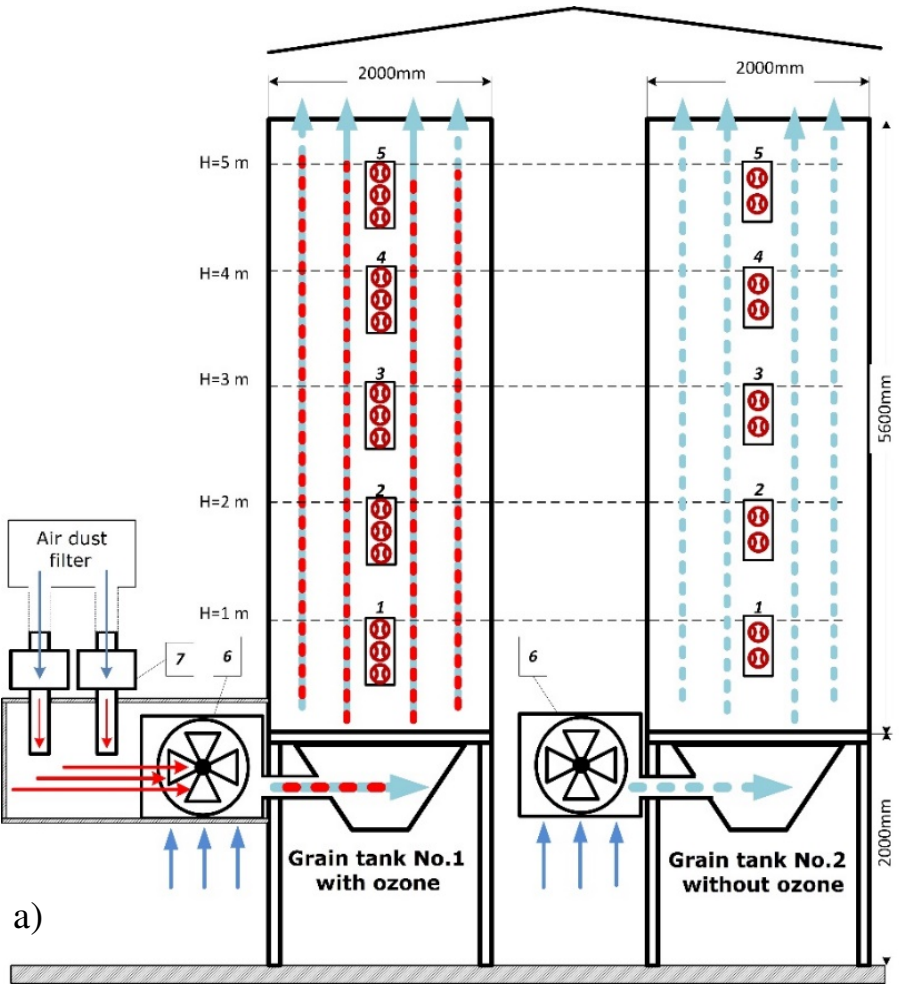

b)

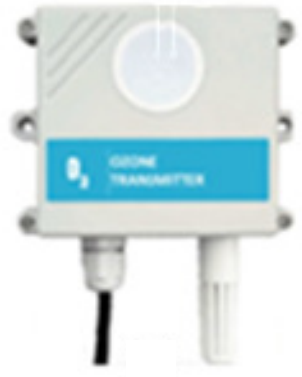

c)

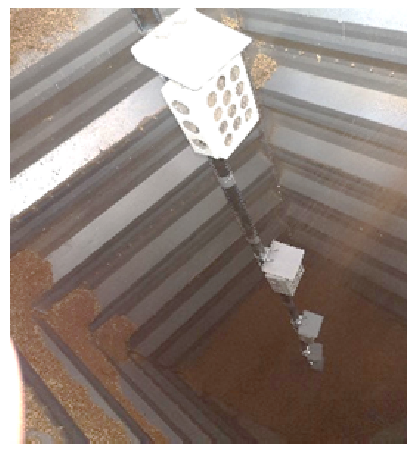

Fig. 1. Grain tanks (a); element of the sensor system (b); location of the sensor system in the tank (c): $1-5$ - sensors; 6 - fan; 7 - ozone generator

\section{Results and discussion}

Winter wheat was loaded into tanks for starting experiments on Mazkalnini farm on 26.07.2019; the experiments started on 27.07.2019 and continued until 19.08.2019. The layer is about $5.1 \mathrm{~m}$ high, the initial moisture of grain $23 \%$, the approximate weight of grain $17.4 \mathrm{t}$ in each tank. At the end of July - in the first half of August, during the days without rain, the most frequent duration of aeration was from $11 \mathrm{am}-9: 30 \mathrm{pm}$. At night the fans were turned off. The parameters recorded by the sensor system at the current moment and on the previous days could be followed on the computer both on the peasant farm Mazkalnini and remotely. Since the sensors in each tank are set up on five levels, on each level three sensors in the ozone tank, and two sensors in the tank without the supply of ozone, as well as two sensors for registration of the moisture of the ambient air and temperature, the total number of operating sensors is 27 , which determine the parameters in every five seconds.

Changes in the data, discovered by the sensors in the microcontroller memory, are recorded only if the difference between the recorded data is greater than a set value $\left(0.5^{\circ} \mathrm{C}\right.$ for temperature, $0.5 \%$ for humidity, and $0.3 \mathrm{ppm}$ for ozone). However, the total amount of the recorded data is very large; therefore further, as an example, the graphs of the changes of the moisture in the inter-grain space, temperature and the ozone concentration are inserted in a period of 9-12 days. The graphs are obtained by processing the real-time measurement display and the graphic representation on a particular day.

The sensor system, when recording air humidity in the inter-grain space, detected an intense moisture decrease in the lower layer during the first week, and only 6-7 days after ventilation started also in the second layer from below. Besides, in the tank with the ozone supply (tank No.2), the humidity in the lower layer all the time was by 6-8 \% lower than in the tank without ozone (Figures 2 and 3), which is apparently connected with the impact of ozone. As the measurements with a hand instrument show, at the end of the second week (07.08.2019) the humidity at the top of the tanks had decreased little - to $17.5 \%$ in the ozone tank and $18.5 \%$ in the tank without ozone; at the same time, the grain in the lower part of the tank was over dried - moisture $11 \%$. The data of the sensor system show that drying of grain has started in the third layer from the bottom, while the humidity in the upper layers in the inter-grain space had changed minimally. 


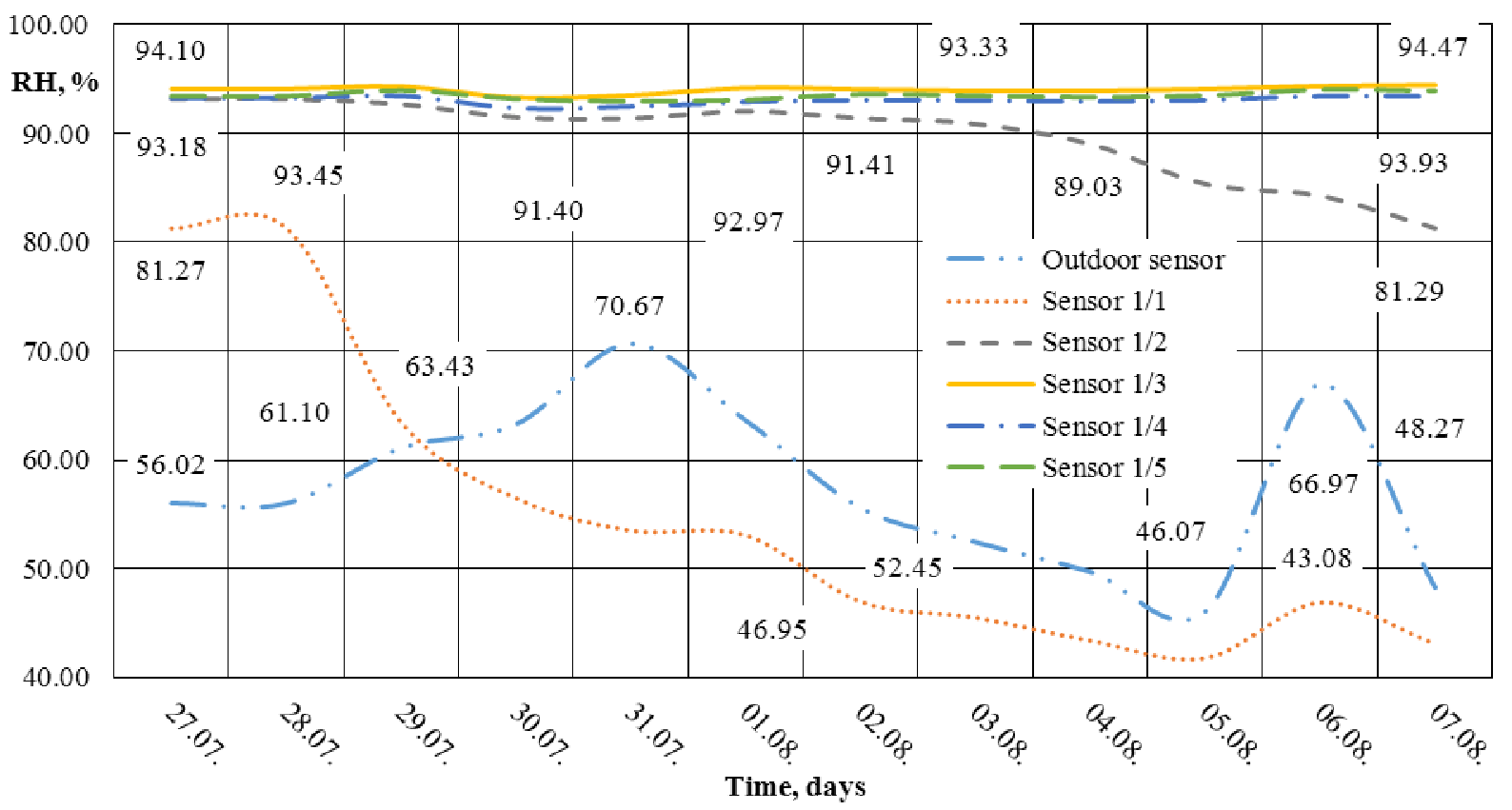

Fig. 2. Air humidity RH \%, tank No.1 (without ozone), 27.27.-07.08.2019

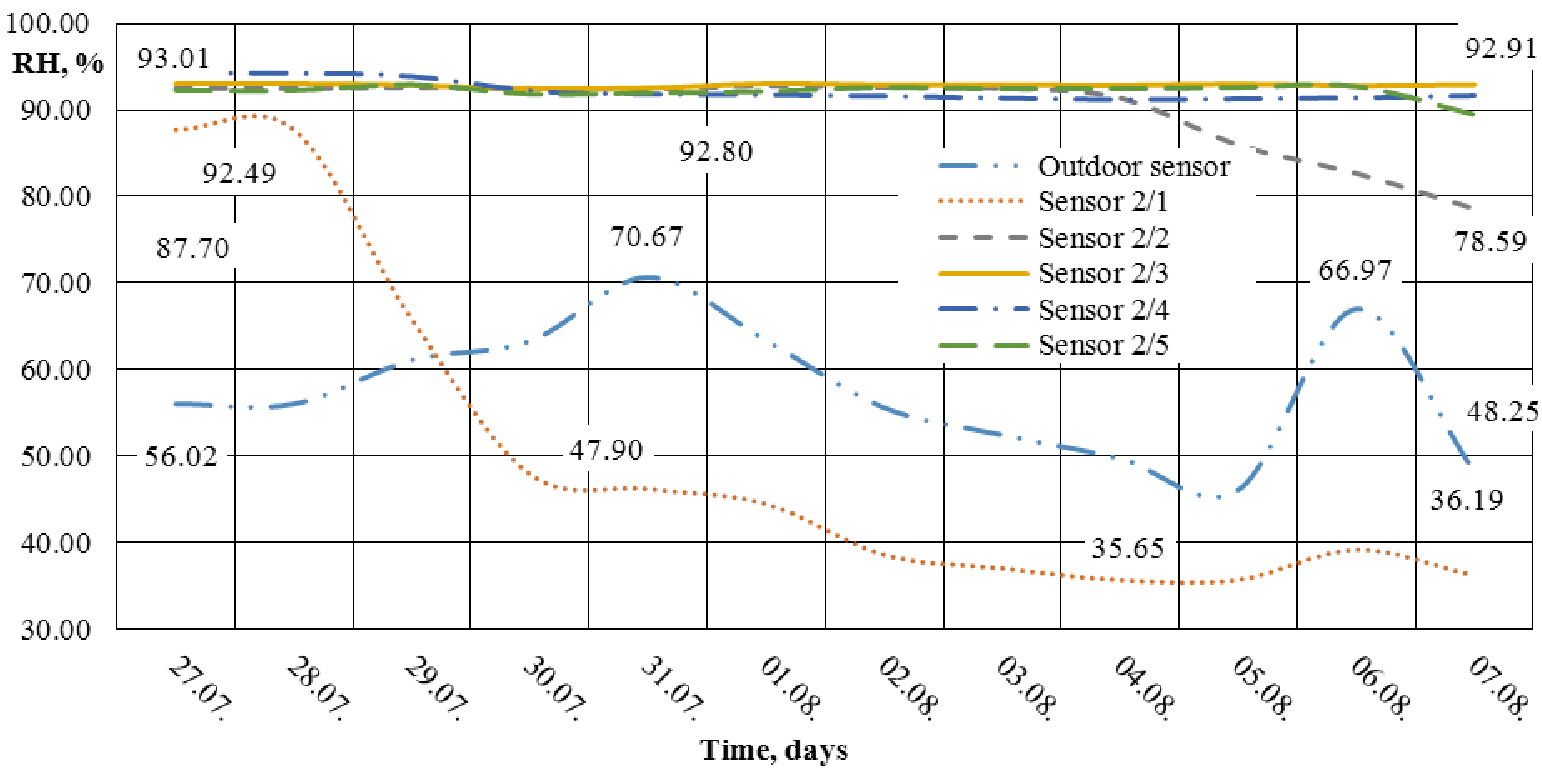

Fig. 3. Air humidity RH \%, tank No. 2 (with ozone), 27.07-07.08.2019

Ozone concentration is the highest in the lower layer, reaching the peak on the fourth day; after that it starts gradually decreasing. In the second and third layers the ozone concentration is relatively constant, in the fourth and fifth layers minimal (Fig. 6).

The following is a brief evaluation of the experiments and results. As already mentioned, the ventilation of both tanks had started at the grain moisture $23 \%$ at the top of the tanks and at the depth of $1.5 \mathrm{~m}$ from the top. The grain samples were taken at $1.5 \mathrm{~m}$ depth with a probe intended for this purpose. Every day the parameters, registered by the sensor system, were monitored, and samples were taken daily at the top of the tanks and at a depth of $1.5 \mathrm{~m}$ with subsequent moisture measurement by means of the said moisture meter. It was found that in the upper layers the grain moisture decreases by $0.5-0.6 \%$ per day during the week, till it reaches approximately $18 \%$ in the ozone tank and $19 \%$ in the tank without ozone. In the following period the moisture of grain in the upper layers does not change, which can be explained by condensation of moisture carried out from the lower layers to the upper part of the tanks. 


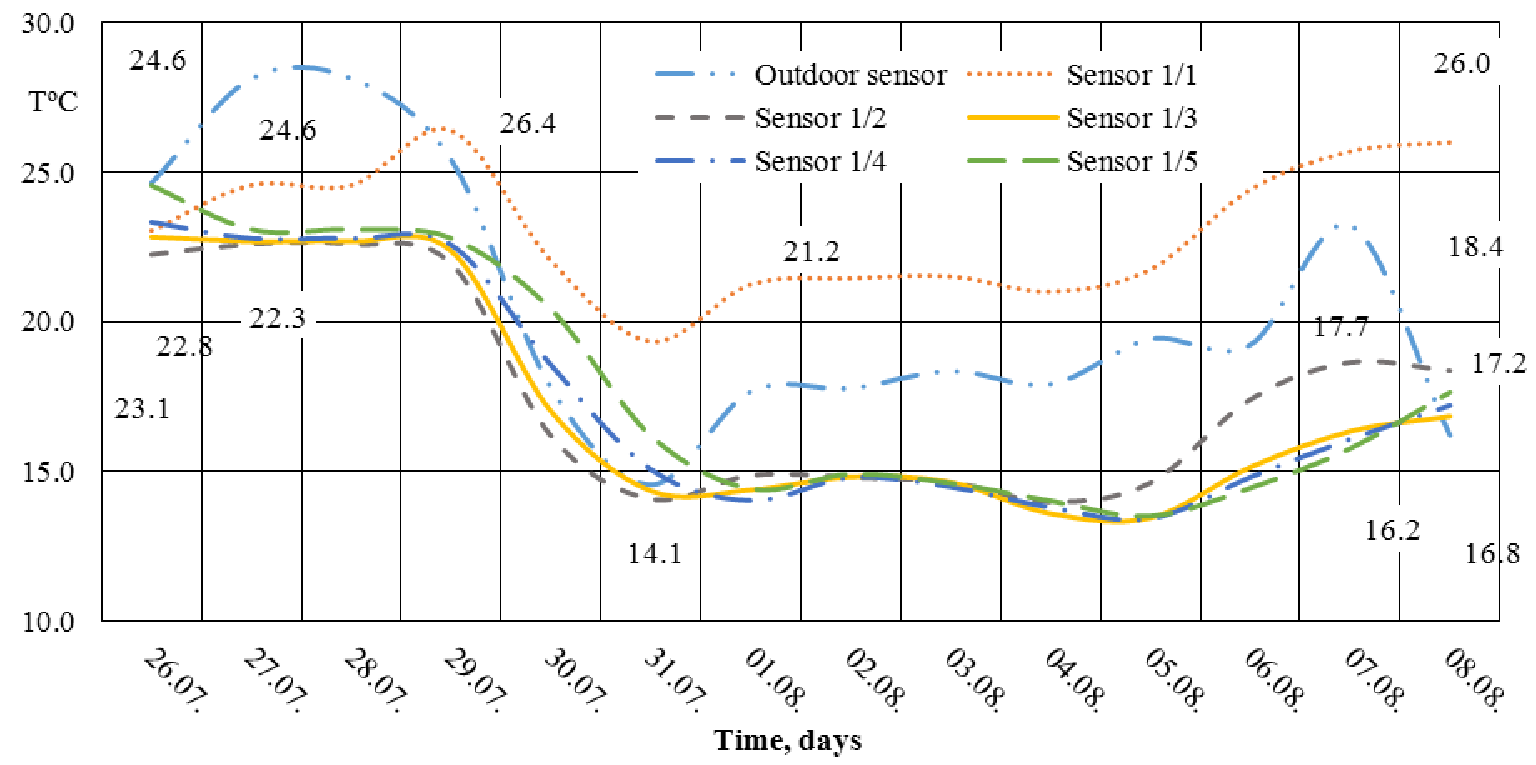

Fig. 4. Temperature ${ }^{\circ} \mathrm{C}$, tank No.1 (without ozone), 26.07-08.08.2019

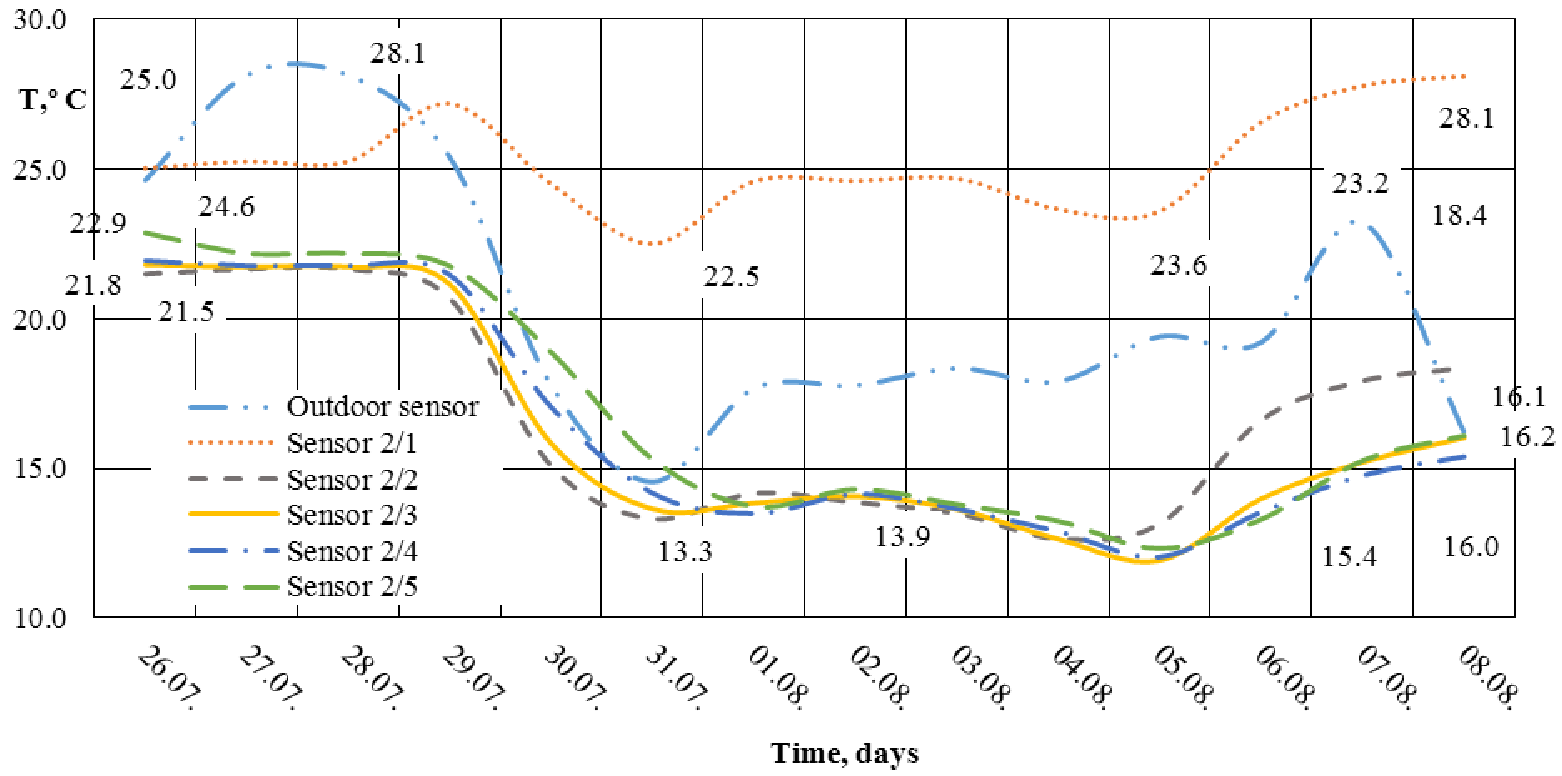

Fig. 5. Temperature ${ }^{\circ} \mathrm{C}$, tank No.2 (with ozone), 26.07-08.08.2019

The air flow rate at the top of the tanks and the ozone concentration, when feeding into the intake pipe of the fan, and at the top of the tank was periodically measured by hand tools. The air flow above the grain layer, depending on the position of the measuring instrument relative to the centre of the tank, was $0.05-0.06 \mathrm{~m} \cdot \mathrm{s}^{-1}$, which is at least twice less than the minimum required for intense ventilation $[4 ; 10]$. The ozone concentration in the inlet of the fan is $15-18 \mathrm{ppm}$, which is even higher than the planned concentration $13 \mathrm{ppm}$, or $28 \mathrm{mg}$ of ozone per $\mathrm{m}^{3}$. The ozone concentration at the top of the tank is approximately $0.1 \mathrm{ppm}$, which means that practically all the ozone has been absorbed as confirmed also by the readings of the sensor system - at levels four and five the ozone is negligible.

To sum up the results of two weeks' experiments, we can conclude that significant drying of grain has occurred in the first three layers from the bottom, whereas in the first layer the grain was significantly overdried. The reason for the high grain moisture in the upper layers is apparently insufficient ventilation air velocity in the grain layer (see the results of the previous measurements), or insufficient specific air consumption in $\mathrm{m}^{3}$ per $\mathrm{m}^{3} \cdot \mathrm{h}^{-1}$ - cubic meters of air per $1 \mathrm{~m}^{3}$ of grain per hour. In our case this indicator is $350 \mathrm{~m}^{3}$ per $\mathrm{m}^{3} \cdot \mathrm{h}^{-1}$, the optimum would be 500-550 [10]. Since it is not possible to increase the efficiency of the fans, it was decided for the intensification of the process to 
reduce the height of the grain layer in the tanks by approximately half, discharging a part of the driest grain from the bottom of the tanks and taking it to the market. As a result, 18.2 tons of grain were delivered from both tanks to the market, from the ozone tank with an average humidity of $17.5 \%$, and from the tank without an ozone supply, with an average humidity of $17.8 \%$.

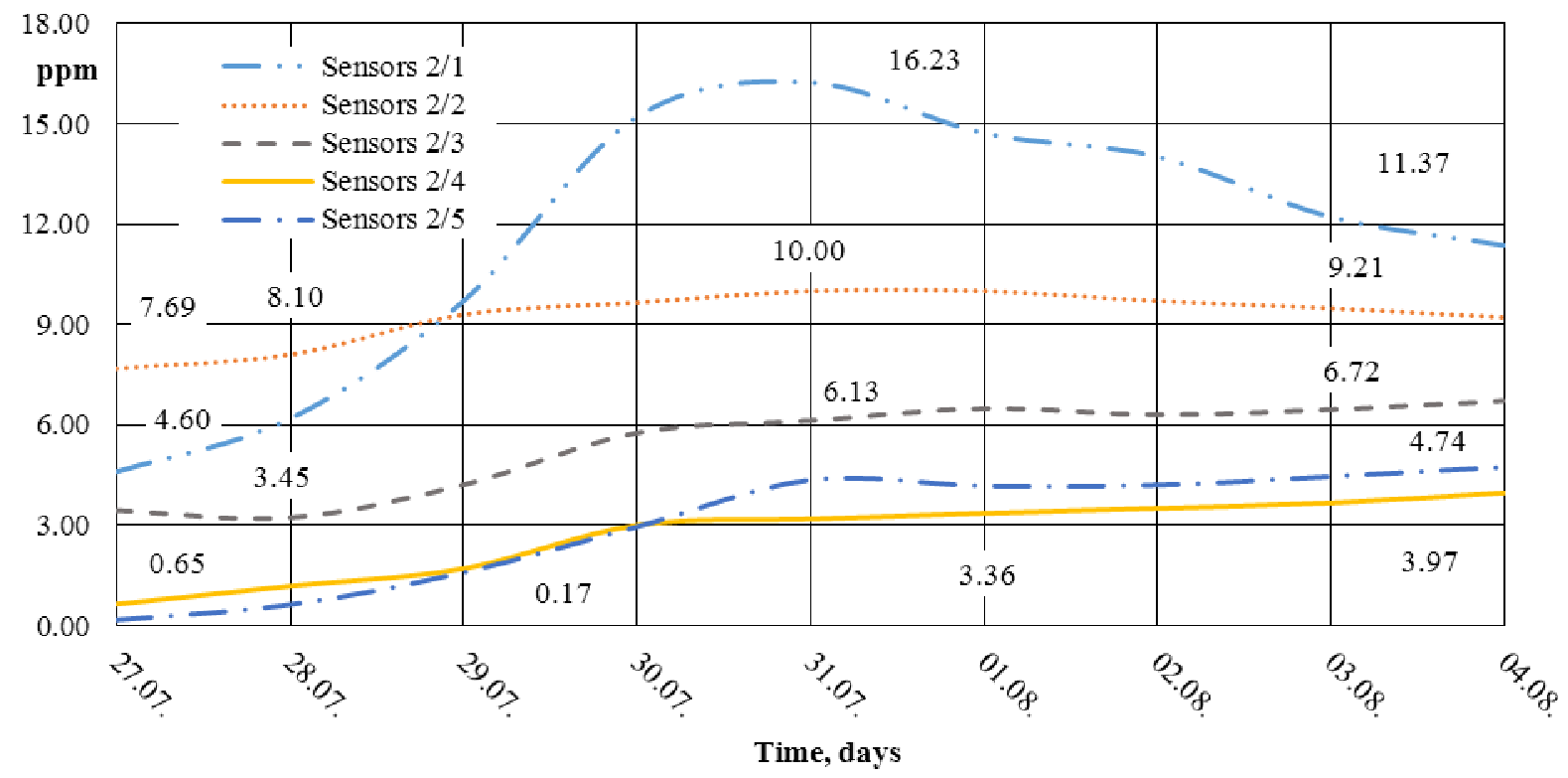

Fig. 6. Ozone concentration $\mathrm{O}_{3} \mathrm{ppm}$, tank No. 2, 27.07-04.08.2019

Since 08.11.2019 aeration of the remaining grain continued - about $1 / 2$ of the tank volume. Parameter monitoring with a sensor system and periodic control measurements with hand tools continued. At the top of the tanks and at a depth of $1.5 \mathrm{~m}$ humidity is initially $18.0 \%$ in the ozone tank and $19.0 \%$ in the tank without ozone; in the bottom of the tanks $15.0 \%$ and $16.3 \%$, respectively. As intense ozone attachment to grain is no longer expected, the ozone generator is operated only periodically - mainly for measurements with hand instruments. The air flow over the grain layer is, on the average, $0.15 \mathrm{~m} \cdot \mathrm{s}^{-1}$, which is three times higher than at full tank and close to optimum. The ozone concentration in the inlet of the fan is likewise 15-18 ppm, while over the top of the grain 1.5-1.7 ppm, on the top of the tank 0.7-1.0 ppm; so, such an efficiency of the ozone generator is quite sufficient for processing a grain layer $3 \mathrm{~m}$ thick. Energy consumption for operating ozone generators $1.9 \mathrm{kWh} \cdot \mathrm{h}^{-1}$

As ventilation continued, on the following days humidity in the lower layers of the tanks decreased relatively rapidly; however, at the top of the tanks humidity even slightly increased. After about a week the grain humidity at the bottom of the tanks was already $11-12 \%$, and after another two days even 10-11\%; so, ventilation was interrupted. On 20.08.2019 there were 14.6 tons of grain sent to market, from the ozone tank with average humidity of $15.2 \%$, from the tank without ozone with average humidity of $15.4 \%$.

\section{Conclusions}

1. Initially the height of the grain layer exceeded $5 \mathrm{~m}$, so it was not possible to reach the required air flow rate of grain, and in the upper layers the grain drying was inadequate, while in the lower layers grain was overdried. Ozone concentrations only in the first and the second layers were optimal, in the third layer approximately a half of the required concentration, on a higher level the impact of ozone was minimal.

2. At the height of the grain layer $3 \mathrm{~m}$ it was possible to provide the required air flow rate $\left(0.15 \mathrm{~m} \cdot \mathrm{s}^{-1}\right)$ and ozone concentration, consequently, sufficient drying intensity; yet it was not possible to find any significant differences in the parameters of the two tanks. It is reported in literature that intense ozone attraction occurs during the first 24 hours of aeration, but if a massive, $5 \mathrm{~m}$ high, has been aerated previously, the grain has already been treated several times with a small ozone concentration; therefore, it was not possible to establish an essential influence of ozone. 
3. During the experiments with the sensor system, the hand tools, and grain sales a slight decrease in the grain humidity in the ozone tank has been found, as compared to the tank without an ozone additive in the ventilation air, yet the advantages of the method have not been convincingly proved. Therefore, experiments should be continued in 2020 during the harvesting season, by ventilating both tanks for grain, 3.0-3.5 $\mathrm{m}$ high.

4. The sensor systems, developed and installed in the tanks, worked without fail, providing a possibility to follow the ventilation modes in the computer, both on the farm, and remotely. Particularly important under the production conditions was the possibility to control the grain temperature in the tanks by layers at high initial moisture of grain, above $20-21 \%$.

It has been proved during the experiments that, using active ventilation, we can prepare extra quality food grain for sale, reducing humidity by 7.0-8.0 \% .

\section{Acknowledgements}

The financial support of the Rural Support Service project No 18-00-A01620-000003 "Technology development of grain drying with active ventilation using ozone" is greatly acknowledged. The authors thank for the support and active cooperation the representatives of the farm "Mazkalniņi” Dr.sc.ing. Aivars Cēsnieks and ing. Sandris Cēsnieks.

\section{References}

[1] Aboltins A., Palabinskis J., Lauva A.. Grain active ventilation using ozonized air. Acta Horticulture 2010. 858, pp. 449-456. DOI: 10.17660/ActaHortic.2010.858.69

[2] Granella S.J. et.al. Effect of drying and ozonation process on naturally coantaminated wheat seeds. Journal of cereal science 80, 2018, pp. 205-211. DOI: 10.1016/j.jcs.2018.03.003

[3] Steponavičienè A., Steponavičius D., Raila A., Kemzūraitè A. Modelling the ozone penetration in a grain layer. Journal of Environmental Engineering and Landscape Management, 20(4), 2012, pp. 292-300. DOI: 10.3846/16486897.2011.645826

[4] Штанько Р.И. Электроозонаторная установка для сушки зерна. Автореферат диссертации на соисание ученой степени кандидата технических наук. 23 с., Зерноград, АЧГАА, 2000. Electroozonator installation for drying grain. Abstract of the dissertation of a doctor of technical sciences. 23 pages, Zernograd, AČGAA, 2000. (In Russian).

[5] Голубкович А. В. идр. Эффективность применения озонно-воздушных смесей в процессах сушки зерна. Материалы 26-го всеросийского семинара (г. Москва, Хим. Факультет МГУ им. Ломоносова, 18.дек. 2003г.) - М.: Изд-во Унивеситет и школа, 2003, - с. 67-86. The efficiency of the use of ozone-air mixtures in the drying processes of grain. Materials of the 26th All-Russian Seminar (Moscow, Chem. Faculty of Moscow State University named after Lomonosov, December 18, 2003) - Moscow: Publishing House of the University and the School, 2003, - pp. 67-86. (In Russian).

[6] Raila A., Lugauskas A., Steponavičius D., Railienė M., Steponavičienė A., Zvicevičius E. Application of ozone for reduction of mycological infection in wheat grain. Annals of Agricultural and Environmental Medicine 13 (2), 2006, pp. 287-294.

[7] Троцкая Т.П. Электроактивирование процессов сушки растительных материалов. Автореферат диссертации доктора технических наук. 32с., Москва, ГАУ, 1998. Electroactivation of drying processes of plant materials. Abstract of the dissertation of a doctor of technical sciences. 32 pages, Moscow, GAU, 1998 (In Russian).

[8] Kleperis J., Vorohobovs V., Cēsnieks S., Vilde A., Cēsnieks A. Application of ozone and environmental monitoring methods in grain drying. Proceedings of $4^{\text {th }}$ International Scientific conference "Agricultural Engineering Problems". Jelgava, 2005, pp. 75-78.

[9] Danchenko V.G. (Dnipropetrovsk, UA), Noyes, Ronald T. (Stillwater, OK, US), Potapovych, L.P. (Dnipropetrovsk, UA). Method of aeration disinfecting and drying grain in bulk and pretreating seeds and a transverse blow silo grain dryer therefor.United States Patent Application Publication, Pub.No: US 2009/0191091 A1, Pub. Date: Jul.30, 2009.

[10] Berziņš E. Graudu kondicionēšana. (Grain Conditioning) 1.-41. lpp, Rīga, Liesma, 1984. (In Latvian). 